\title{
Non-Skeletal Biomineralization by Eukaryotes: Matters of Moment and Gravity
}

\section{Citation}

Raven, John A., and Andrew H. Knoll. 2010. Non-skeletal biomineralization by eukaryotes: matters of moment and gravity. Geomicrobiology Journal 27(6\&7): 572-584.

\section{Published Version}

doi:10.1080/01490451003702990

\section{Permanent link}

http://nrs.harvard.edu/urn-3:HUL.InstRepos:4795339

\section{Terms of Use}

This article was downloaded from Harvard University's DASH repository, and is made available under the terms and conditions applicable to Open Access Policy Articles, as set forth at http:// nrs.harvard.edu/urn-3:HUL.InstRepos:dash.current.terms-of-use\#OAP

\section{Share Your Story}

The Harvard community has made this article openly available.

Please share how this access benefits you. Submit a story.

Accessibility 


\title{
Non-Skeletal Biomineralization by Eukaryotes: Matters of Moment and Gravity
}

\author{
John A. Raven \\ Division of Plant Sciences, University of Dundee at SCRI, Scottish Crop Research Institute, \\ Invergowrie, Dundee, DD2 5DA, UK
}

\begin{abstract}
Andrew H. Knoll
Department of Organismic and Evolutionary Biology, Harvard University, Cambridge MA 02138, USA
\end{abstract}

\begin{abstract}
Skeletal biomineralisation by microbial eukaryotes significantly affects the global biogeochemical cycles of carbon, silicon and calcium. Non-skeletal biomineralisation by eukaryotic cells, with precipitates retained within the cell interior, can duplicate some of the functions of skeletal minerals, e.g. increased cell density, but not the mechanical and antibiophage functions of extracellular biominerals. However, skeletal biomineralisation does not duplicate many of the functions of non-skeletal biominerals. These functions include magnetotaxis (magnetite), gravity sensing (intracellular barite, bassanite, celestite and gypsum), buffering and storage of elements in an osmotically inactive form (calcium as carbonate, oxalate
\end{abstract}


polyphosphate and sulfate; phosphate as polyphosphate) and acid-base regulation, disposing of excess hydroxyl ions via an osmotically inactive product (calcium carbonate, calcium oxalate). While polyphosphate has a wide phylogenetic distribution among microbial eukaryotes, other non-skeletal minerals have more restricted distributions, and as yet there seems to be no definitive evidence that the alkaline earth components ( $\mathrm{Ba}$ and $\mathrm{Sr}$ ) of barite and celestite are essential for completion of the life cycle in organisms that produce these minerals.

Keywords: Ballast, Barite, Bassanite, Calcium carbonate, Calcium oxalate, Celestite, Gypsum, Magnetite, Magnetotaxis, Polyphosphate, Statoliths 


\section{INTRODUCTION}

Biomineralization is commonly discussed in terms of the contrast between two distinct processes, biologically-induced mineralization, associated principally with bacterial metabolism, and biologically-controlled mineralization, epitomized by skeleton formation in eukaryotic organisms. There is, however, another type of biologically-controlled mineralization that occurs across life's three domains: non-skeletal mineral precipitation within cells. These precipitates form within intracellular vesicles under tight enzymatic control, and, like skeletons, they have specific functions that contribute to overall fitness. Indeed, skeletal mineralization in protists and sponges has much in common with non-skeletal mineralization within cells, taking place inside intracellular compartments bounded by membranes and characterized by local expression of genes for the enzymes and templating molecules that guide precipitation. In a very real sense, then, the skeletal precipitation of silica by radiolaria, diatoms, and many other protists (e.g., Knoll 2003; Raven \& Giordano 2009) and the formation of calcitic scales by coccolithophorid algae (e.g., Young \& Henriksen 2003) may be particular examples of a broader phenomenon. Here, we examine the greater breadth of controlled biomineralization by eukaryotic microorganisms: the magnetosomes, statoliths, calcium oxalate raphides, and polyphosphate bodies found in diverse protists, with additional reference where appropriate to their occurrence in plants and animals.

\section{MAGNETITE AND MAGNETOTAXIS}

Magnetite $\left(\mathrm{Fe}_{3} \mathrm{O}_{4}\right)$ has two roles in biology. One exploits its hardness: magnetite in the radulae of polyplacophoran mollusks (chitons) facilitates the scraping of food from rock surfaces. The other role makes use of its magnetic properties: magnetite plays a role in metazoan 
navigation and in magnetotaxis by some motile bacteria and unicellular eukaryotes. In protists that display magnetotaxis, small magnetite crystals occur, as in magnetotactic bacteria, within magnetosomes. These magnetosomes appear to be intracellular vesicles with a surrounding lipid bilayer membrane; however, detailed electron cryotomographic studies of bacterial magnetosomes show that the magnetosomes are invaginations of the cell membrane, so that the that magnetite crystals are topologically in the periplasm (Komeili 2007). No comparable data are available for the magnetosomes of protists. This has been observed in a colourless phagotrophic euglenoid from brackish sediment in a Brazilian mangel (Torres de Araujo et al. 1986) and in a colourless dinoflagellate, a ciliate and two cryptomonads, all non-photosynthetic phagotrophs, in chemically stratified coastal saline pools (Bazylinski et al. 2000).

Magnetotaxis is distributed widely, if sporadically, in eukaryotic phylogeny, having been documented in alveolates (ciliates and dinoflagellates), early branching chromalveolates (two cryptomonads), and an excavate/discicristate (euglenoid), not to mention magnetite precipitation within the Metaoza. This distribution has been interpreted as an indication that biologicallycontrolled magnetite precipitation is a fundamental feature of eukaryotic biology, present in the last common ancestor of extant Eucarya (Vali \& Kirschvink 1991). Such speculation is consistent with geological evidence that places early eukaryotic diversification within oceans that commonly developed subsurface anoxia beneath moderately oxic surface waters (e.g., Anbar \& Knoll 2002). Confidence in broad evolutionary conclusions, however, is undermined by uncertainties concerning the biosynthetic origin of magnetite in magnetotactic protists. Known magnetotactic protists are phagotrophic and co-occur with magnetotactic bacteria (Torres de Araujo et al. 1986; Bazylinski et al. 2000). This raises the possibility that the magnetosomes in the eukaryotes are obtained from ingested bacteria, although no ingestion of the abundant 
magnetotactic bacteria in the environment has been observed (Bazylinski et al. 2000, 2007), and iron could also be obtained by phagotrophy of non-magnetotactic bacteria or colloidal iron, an option not open to magnetotactic bacteria (Maranger et al. 1998; Nodwell \& Price 2001). Magnetosomes certainly increase the amount of iron required by cells significantly. From the percentage of the cell volume of a colourless euglenoid occupied by magnetite (Torres de Araujo et al. 1986), the density of magnetite, and the assumption that the dry matter is $45 \%$ carbon and is one-third of the fresh weight, the Fe in magnetite per total cell $\mathrm{C}$ is $6500 \mu \mathrm{mol}$ per mol. This is two orders of magnitude greater than the $60 \mu \mathrm{mol} F e$ per mol C in 15 species of nonmagnetotactic eukaryotic marine phytoplankton from nutrient-sufficient cultures (Ho et al. 2003).

The "kleptomagnetosome" suggestion is consistent with similarities in structure of magnetite crystals in some magnetotactic protists and in co-occurring bacteria (Bazylinski et al. 2000, 2007), although it could also be argued that there are few structure-function options for magnetosome morphology in unicellular organisms. Magnetosome morphology in magnetotactic euglenoids, however, is distinctly more complex than that found in bacteria or in other unicellular eukaryotes, favoring in situ biosynthesis (Torres de Arranjo et al. 1986; Bazylinski et al. 2007). Magnetosomes in both bacteria and eukaryotes occur in intracellular vesicles; there is no indication from available electron micrographs that the eukaryote magnetosomes occur within a bacterial endosymbiont (Bazylinski et al. 2000). Iron and oxygen isotope signatures of biogenic magnetite in phagotrophic protists and co-occurring bacteria (Mandernak et al. 1999) would be illuminating, although the test is one-sided. Isotopic differences would support arguments for distinct eukaryotic and bacterial biosyntheses, whereas similar isotopic abundances could be interpreted either in terms of ingestion or independent 
precipitation from a common water body. Without question, some eukaryotes (for example, pigeons, honey bees, and chitons) precipitate magnetite, but differentiation between hypotheses that call for early origin and polyphyletic loss of magnetite biosynthesis versus polphyletic origins on various branches of the eukaryotic tree awaits careful research on the possibility of magnetosome derivation from food items.

Biogenic magnetite is characterized by crystollographically oriented chains of chemically pure crystals, commonly elongated along the [111] axis (Thomas-Keprta et al. 2000, Faivre and Schüler 2008), so in sediments it can be differentiated from magnetite of magmatic origin. (Telling biogenic from abiogenic magnetite has proven more controversial in martian meteorites, where it now appears that elongated single domain crystals may have formed during meteoritic impact; Golden et al. 2004). Because biogenic magnetite can be identified in sediments, these crystals have the potential to preserve in the geologic record; indeed, fossils of biogenic magnetite are relatively abundant and go back to the Middle Archaean (Chang et al. 1989). Geochemical data indicating that Archean oceans were neutral to reducing, with little or no free oxygen, require that anaerobic processes must have been used to oxidize $2 \mathrm{Fe}(\mathrm{II})$ to $2 \mathrm{Fe}(\mathrm{III})$ for each $\mathrm{Fe}$ as $\mathrm{Fe}(\mathrm{II})$ in magnetite. In sedimentary rocks deposited after global atmospheric oxygenation 2.4 billion years ago and after the origin of eukaryotes (in place by 1.8 billion years ago), there is the possibility of a eukaryotic origin for some magnetofossils, although allocating these later biogenic magnetites to Eukarya or Bacteria is rarely attempted. While Schumann et al. (2008) suggest a eukaryotic origin for the large (up to $4 \mu \mathrm{m}$ long) spearhead or spindle-shaped magnetite found in marine sediments from the Paleocene-Eocene Thermal Maximum $(\sim 55.6$ million years ago), Lippert (2008) suggests that the large magnetofossils could alternatively have 
come from very large bacteria comparable to those found in some high-productivity shelf environments today.

As for the possible selective advantage of magnetotaxis in unicellular eukaryotes, all five known examples occur in two saline coastal habitats characterised by physical and chemical stratification, with oxygenated surface waters lying atop a hypoxic or anoxic water mass (Torres de Araujo et al. 1986; Bazylinski et al. 2000, 2007). Torres de Araujo et al. (1986) point out that the Brazilian mangel is within $4^{\circ}$ of the equator, so magnetotaxis there would lead to horizontal swimming, perhaps also following a zone of specific chemical composition such as oxygen concentration at the oxic/anoxic transition zone. Such tracking of this transition zone has also been suggested for high latitude magnetotactic organisms (Frankel et al. 1997), although the obvious magnetotactic response would not yield near vertical rather than horizontal movement. Bazylinski et al. (2000) cite work showing that some microaerophilic ciliates use gravitaxis as part of a broader behavioral mechanism for aerotaxis. While magnetite particles have a higher density than the general cell contents (Table 1), a role in graviperception is unlikely in view of the unavoidable force exerted on them by the Earth's magnetic field. By increasing overall cell density magnetosomes increase the energy cost of upward movement at a given speed and decrease that of downward movement. Graviperception in the ciliates involves Müller bodies, biomineralized microconcretions that contain either strontium or barium as celestite and barite, respectively (Hemmersbach \& Häder 1999; Bazylinski et al. 2000; Hemmersbach et al. 2005). These two elements also occur as the biominerals barite $\left(\mathrm{BaSO}_{4}\right)$ and celestite $\left(\mathrm{SrSO}_{4}\right)$ in charophycean algae such as desmids and Charales, with a known gravitropic role for barite particles in the rhizoids of the Charales (see below). In this case there is no known connection to aerotropism, although the Charales often grow with their rhizoids in hypoxic or anoxic 
sediments. The role of barite and celestite in eukaryotic microbes is considered in more detail below.

The use of magnetotaxis or gravitaxis by protists to maintain position in relation to the oxic/anoxic transition cannot entirely substitute for a chemotactic response that detects oxygen directly (e.g., via a receptor such as haemoglobin), or through detection of an oxidationreduction surrogate of oxygen (e.g., ferritin binding of iron). Thus far, the ecological distribution of magnetotaxis in protists is restricted to two chemically-stratified coastal marine habitats. They could perhaps also occur in inland waters, deeper marine sediments, and in such offshore pelagial marine habitats as the central Black Sea that have appropriate oxyclines.

A final evolutionary point is whether the occurrence of magnetite in magnetosomes in eukaryotes evolved in relation to magnetotaxis, or was co-opted from a function unrelated to magnetoperception.

\section{BARITE, CELESTITE AND GRAVIPERCEPTION}

Just as magnetite's magnetic properties enable magnetotaxis, the specific gravities of barite and celestite facilitate gravitaxis. Barite $\left(\mathrm{BaSO}_{4}\right)$ and celestite $\left(\mathrm{SrSO}_{4}\right)$ have densities well in excess of other cell constituents, including other common mineralized components (Table 1). Two clades of charophyte green algae are known to precipitate barite: barite (or celestite) particles occur in vesicles at the tips (poles) of the two hemicells of placoderm desmids and in some other members of the Zygnematales-Desmidales clade, while barite, usually with some celestite, occurs in the tips of rhizoids in some Charales (Raven \& Giordano 2009; see also Kreger \& Boere 1969; Sievers and Schmitz 1982). The latter particles act as statocytes in graviperception, guiding positively gravitropic growth of the rhizoids. 
Celestite, with a small fraction of barite $(\mathrm{Ba} / \mathrm{Sr} \sim 0.003)$, is the inorganic component of skeletons and cysts made by Acantharia (Bernstein \& Byrne 2004; De Decker 2004), members of the Rhizaria that are sister to the silica secreting polycystine radiolarians (Kunimoto et al. 2006). Celestite occurs as crystals in the cytoplasm of the flagellate swarmers of some colonial radiolarians/acatharians (Hughes et al. 1989; Anderson et al. 1990). Some ciliates (Alveolata) have Müller bodies containing celestite or barite that act as statocytes in graviperception of these gravitactic organisms (Hemmersbach \& Häder 1999; Hemmersbach et al. 2005). Finally, barite particles occur in at least two plankonic flagellate species within the Chromista (phylum Haptophyta; class Prymnesiophyceae, order Pavlovales; Fresnel et al. 1979, Gayal and Fresnel 1979). Function is uncertain for these flagellates, but might enable graviperception. Like magnetite, then, barite and celestite occur broadly but sporadically in eukaryotic phylogeny, arguing in this case for a polyphyletic origin of $\mathrm{Ba} / \mathrm{SrSO}_{4}$ precipitation.

As far as we can determine there has been no published attempt to determine whether $\mathrm{Ba}$ and $\mathrm{Sr}$ are essential elements for barite- and celestite-producing organisms, in the sense of inability to complete their life cycle under axenic culture conditions in as near complete absence of the element under investigation as can be obtained. Of course, even if $\mathrm{Ba}$ and $\mathrm{Sr}$ turned out to be non-essential by this definition, these elements could still have significant roles in increasing fitness in the field.

$\mathrm{CaSO}_{4}$ is much less common in eukaryotic microbes, though it is deposited as the main mineral in some desmids (Brook 1981) and is a minor component of the statoliths in some characeans (Schroter et al. 1975; Sievers \& Schmitz 1982). It is not certain what mineral form of $\mathrm{CaSO}_{4}$ is deposited in the eukaryotic microbes. In scyphozona and cubozoan medusae (Phylum Cnidaria) statoliths are formed of bassanite, ie. $\left(\mathrm{CaSO}_{4}\right)_{2} \cdot \mathrm{H}_{2} \mathrm{O}$ (Tiemann et al. 2002, 2006). 
Bassanite is not the morph that is most readily precipitated from solution, but it has a significantly higher density than gypsum $\left(\mathrm{CaSO}_{4} \cdot 2 \mathrm{H}_{2} \mathrm{O}\right)$, to which bassanite spontaneously transforms when placed in contact with water (Tiemann et al. 2002, 2006; Zhang \& Sekine 2007).

Expanding on the occurrence of barite or celestite in graviperception, all charalean species have barite statocytes that are known to function in positive graviperception. By contrast, barite or celestite statocytes (or any other statocytes) are relatively rare in gravitropic ciliates and flagellates (Hemmersbach \& Häder 1999; Hemmersbach et al. 2005). Graviperception in the absence of statocytes is apparently a result of gravity on the cytoplasmic contents acting on stretch-sensitive ion channels in what, for the moment, is the lower part of the plasmalemma. Such a mechanism does not require a particular spatial arrangement of denser components of the cytoplasm. If denser components of the cell are at one peripheral part of the cell then this part of the cell will orient at the bottom; this can cause positive gravitaxis if the placement of the ballast relative to the flagella and their direction of functioning causes downward swimming, or vice versa for negative gravitaxis (Hemmersbach \& Häder 1999; Hemmersbach et al. 2005). This passive orientation does not involve movement of the denser components relative to the intracellular components of the cell, thereby differing from the statocyte mechanism. As does magnetite in magnetotactic protists, statocytes in swimming cells increase overall cell density, increasing the energy needed to swim upward at a given speed; conversely less energy is required for downward swimming. The function of barite crystals in the polar vacuoles of placoderm desmids is unclear.

There are well-preserved fossils both of desmids with a morphology resembling that of extant Closterium (Baschnagel 1966; Waggoner 1994) and of rhizoid-bearing of Charales 
(Kelman et al. 2004), but neither contain barite or celestite particles, perhaps reflecting dissolution during diagenesis.

It is hard to discuss gravitaxis and sulphate biomineralization without considering the celestite-precipitating Acantharia. Acantharians are abundant members of the marine microplankton. They commonly outnumber planktonic foraminifera and radiolarians, but because they do not fossilize well, they are less well known. Acantharians leave few fossils because at all depths the ocean is significantly undersaturated with respect to celestite, causing their skeletons to dissolve (De Decker 2004). The cost of biomineralization for any mineral relates to saturation levels in ambient fluids. Given the marked undersaturation of seawater with respect to celestite, celestite precipitation within cells must require active transport of ions into the cytoplasm. Barite forms a solid substitution series with celestite, and the presence of Ba with a $\mathrm{Ba} / \mathrm{Sr}$ of $3 \pm 0.8 \cdot 10^{-3}$ (Bernstein et al., 1998) lessens the saturation problem somewhat. However, in past oceans, undersaturation would have been stronger, as sulfate abundance in the oceans is higher than it has been for the great majority of Earth history (Gill et al 2007 and references therein). Why celestite, then?

Perhaps celestite precipitation in acantharians is of Cenozoic origin, post-dating both the increase of marine $\left[\mathrm{SO}_{4}{ }^{2-}\right]$ to near modern values and the widespread depletion of silica from surface waters by diatoms. Functionally, the radially oriented spines of acantharian skeletons support axopods, much as silica rods do in radiolarians, but the density of celestite presents a potential problem - unless gravitaxis or orientation is part of skeletal function. One might speculate that acantharians' use of celestite in skeleton formation might represent the cooptation of a pre-existing mineralization pathway that originally evolved for gravity perception. Certainly, this would explain the otherwise puzzling use of this mineral. Unlike the case for 
celestite, seawater is saturated with respect to barite (Rushdi et al. 2000), raising the question of why barite has not been used for skeleton formation. While this would less the physiological cost of precipitation, barite might be too readily precipitated, necessitating inhibitory molecules to shape skeletal elements.

As a final point about the occurrence of dense alkaline earth sulfate crystals in eukaryotic microbial cells, we underscore the obvious point that they unavoidably increase the density of the cells. This is of particular relevance for holoplanktonic cells, and meroplanktonic dispersal stages of benthic organisms (Raven \& Waite 2004; Beardall et al. 2009). This ballast effect is most often considered for plankton with external silica (e.g. diatoms, parmophyceans, radiolarians, silicoflagellates, synurophytes) or calcium carbonate (e.g. coccolithophores, foraminiferans) structures. A point of relevance to this article is that the minerals are deposited internally in all of these cases (except in those foraminiferans that mineralize by agglutination of pre-existing external mineral particles: Table 2), and that the increase in density occurs as soon as the mineral is formed within the cells. Raven and Waite (2004) suggest that ontogeny may reflect evolution: the ballast effects of intracellular silica and calcium carbonate increased fitness before externalisation evolved and added skeletal and other functions that require external minerals. Such a fitness increase would be most obvious if, for example, diatoms and foraminifera evolved silicification as planktonic organisms rather than in the benthos (Raven \& Waite 2004; Sims et al. 2006; Darling et al. 2009); however, in foraminifera, at least, carbonate skeletons appear to have evolved within benthic taxa, long before forams invaded the pelagic realm (Ross \& Ross 1991).

\section{PHOSPHATE MINERALS: POLYPHOSPHATE BODIES AND ACIDOCALCISOMES}




\section{Distribution in eukaryotic microbes}

Apatite (actually carbonated hydroxyapatite, or dahllite; Weiner and Dove 2003) is conspicuously apparent as a biomineral in the skeletons of vertebrate animals. It also occurs in the shells of lingulid brachiopods and several other now extinct clades of Cambrian animals (summarized by Knoll 2003). Nonetheless, animal clades with skeletons of calcium carbonate greatly outnumber those that form phosphatic bones or shells, and, among algae and protozoans, phosphatic skeletons are essentially unknown. A single paper documents calcium and phosphate enrichment in surficial scales of the prasinophycean sensu lato (actually a basal charophycean) green alga Mesostigma viride (Domozych et al. 1991), but whether the observed elemental enrichment records apatite precipitation or cell wall polyphosphates is unclear (see below).

On the other hand, many eukaryotic microbes produce non-skeletal polyphosphate granules, with tens or hundreds of orthophosphate residues in a chain. Hooley et al. (2008) claim that "it (polyphosphate) has been shown to be present in all cells of all species studied", and Rao et al. (2009) state that polyphosphate is "found abundant (sic) in every cell in nature", though we adopt a more conservative stance and cite references for polyphosphate occurrence in higher taxa of eukaryotic microbes, while admitting that inability to detect polyphosphate in a given cell may be a problem of technique (below, and Table 2). The negative charge on the phosphate residues in these granules is balanced by (usually) divalent cations, such as $\mathrm{Ca}^{2+}, \mathrm{Mg}^{2+}$ or $\mathrm{Zn}^{2+}$. The granules are generally intracellular, often surrounded by a lipoprotein membrane. These intracellular, membrane-bounded polyphosphate granules overlap with, but may not be entirely subsumed by, the more recently discovered acidocalcisomes, first characterised in apicomplexan (Alveolata) parasites (Docampo \& Moreno 1999; Docampo et al. 2005). Polyphosphates can also 
occur in the cell wall of the chlorophycean green alga Chlamydomonas reinhardtii (Werner et al. 2007), possibly related to the exocytosis of polyphosphate granules in this organism (Komine et al. 2000). Polyphosphate granules in the broad sense are also been reported from the Opisthokonta (many fungi), non-thecate amoebae (Amoebozoa), Plantae/Archaeoplastida (red algae, charophycean, chlorophycean, trebouxiophycean and ulvophycean green algae), Rhizaria, Alveolata (apicomplexans, dinoflagellates), Chromista: Ochrista (diatoms, chloromonads/raphidophyceans. tribophyceana), Chromista: Haptophyta (coccolithophore) and Excavata/Discicristata (euglenoids): see Table 2.

\section{Function of polyphosphates}

Polyphosphate granules do not serve a biomechanical function similar to that of dahllite skeletons in animals or the carbonate and silica skeletons found in other protists. It could be argued that phosphate is too scarce in nature to be used skeletally, at least in primary producers, as phosphorus availability should ultimately limit primary productivity. Constraints on nitrogen fixation mean that combined nitrogen (i.e. not $\mathrm{N}_{2}$ ) is commonly the element that proximally limits primary production (Vitousek et al. 2002; Raven et al. 2005b; Menge et al. 2008); nonetheless, phosphate storage may enable primary producers to maximize production in water bodies characterized by patchy distribution, and therefore episodic availability, of both phosphate and fixed nitrogen.

Polyphosphate provides a biochemically accessible form of phosphorus in a form that is, in essence, an osmotically inactive form. Interestingly, Docampo and Moreno (1999) do not list phosphate storage among the possible functions of acidocalcisomes, presumably because of their perspective as parasitologists who focus on apicomplexan parasites of metazoans, where 
phosphate limitation of growth is relatively unlikely. A storage role is consistent with observed changes in polyphosphate with variations in phosphorus supply, e.g., for green algae (Eixler et al. 2006; Nishikawa et al. 2006).

Raven (1987) and Raven et al. (2005a) have considered the costs and benefits of the use of polyphosphate rather than accumulation of inorganic orthophosphate in non-acidocalcisomelike vacuoles. There is at least a ten-fold saving in the volume within a cell if a certain amount of phosphate is stored as polyphosphate with chains containing hundreds of phosphate monomers rather than as dissolved monomeric orthophosphate with osmotic constraints on the possible concentration (Raven et al. 2005a). This is important for picoplankton where the cell volume is close to the minimum that is consistent with free-living existence (Raven et al. 2005a), and could also have significance for larger cells (Raven 1987). When considering polyphosphates as storage bodies, we do well to remember that while the total polyphosphate pool changes with phosphate availability in the manner expected of a storage material, phosphorus-limited algae invariably retain some polyphosphate (see also Rao et al. 2009).

At the expense of minimizing the volume associated with phosphate storage, polyphosphate depolymerisation and re-polymerisation might also help cells adjust to changes in external osmolarity. Leitao et al. (1995) showed that the marine diatom Phaeodactylum tricornutum responded to transfer from seawater to a medium of higher salinity by increasing the chain length of polyphosphates and a reduction in extractable polyphosphate, while transfer to a medium of low salinity increased the number of short-chain polyphosphates and total polyphosphate content. It is not clear, however, if the observed changes actually act in osmoregulation. 
While the phosphate anhydride bonds in the polyphosphate have a high in vivo free energy of hydrolysis and so could potentially act as an energy store (Docampo and Moreno 1999), it can be readily calculated that even a polyphosphate content per cell equal to the phosphate required for a cell doubling would only last for a few minutes of providing all of the ATP needed for growth.

A further, unavoidable, outcome of storage of polyphosphate is to increase the density of the cell (Table 1), as indicated by Romans et al. (1994) for the marine diazotrophic cyanobacterium Trichodesmium tenue. In this species, polyphosphates provide, on average, about $20 \%$ of the ballast effect of stored polysaccharides, while nitrogen storage as cyanophycin also makes a contribution. Eukaryotic microorganisms do not synthesize cyanophycin, although storage proteins could act as an analogue, with a higher energy cost of synthesis. For phosphate, eukaryotes have the option of storage as orthophosphate in conventional vacuoles as well in the form of polyphosphate in granules.

Is the ballast effect of storage of phosphorus as orthophosphate the same as that of storage as polyphosphate? This was addressed using calculations similar to those used by Raven et al. (2005a) to determine the relative volumes of storage of a given quantity of phosphate as polyphosphate and as orthophosphate, but including values of the density of polyphosphate granules (Jacobsen et al. 1982) and of solutions of phosphate salts (Boyd and Gradmann 2002). In this case the phosphate stored as 1000 mol orthophosphate per cubic metre with a density of $1060 \mathrm{~kg}$ per cubic metre occupies seven times the volume of the same quantity of phosphate as polyphosphate with a density of $1950 \mathrm{~kg}$ per cubic metre. Ignoring the increment of cell volume in the orthophosphate case, the excess density (over water $=1000 \mathrm{~kg}$ per cubic metre) for orthophosphate is $420 / 950$ or $44 \%$ of that of polyphosphate. The overall ballast effect in causing 
sinking of cells or colonies is clearly greater if a given amount of phosphate is stored as polyphosphate than of orthophosphate.

These arguments are relevant to planktonic photosynthetic eukaryotes that undergo vertical migration over diel or longer time intervals in stratified waters. The rationale is that the surface waters have photosynthetically active radiation but have been stripped of nutrients (phosphorus; combined nitrogen for organisms that cannot fix nitrogen) required for the growth of primary producers, while deeper waters have limited light but higher nutrient concentrations. Acquisition of both light and nutrients can be achieved by vertical migration, employing flagellar activity (cryptomonads, dinoflagellates, raphidophytes, Volvox) or a balance of changes in solute composition of aqueous vacuoles and macromolecular ballast (large diatoms such as Ethmodiscus and Rhizosolenia, the latter frequently with diazotrophic Richelia symbionts; the large dinoflagellate Pyrocystis; phycoma stages of prasinophytes) rather than the balance of gas vesicles and macromolecular ballast as in cyanobacteria (Beardall et al. 2009). Under these circumstances, upward movement is impeded by the ballast effect of polyphosphate or, to a lesser extent, dissolved orthophosphate.

\section{CALCIUM OXALATE WITHIN CELLS}

Euhedral crystals of calcium oxalate have long been reported from vascular plants, where they occur within intracellular vesicles and appear to function in Ca-regulation, defense against predators, and, in some cases, a means of sequestering toxic cations, especially Al (Franceschi \& Nakata 2005). A major function not mentioned by Franceschi and Nakata (2005) is that of acidbase regulation related to nitrate assimilation in shoots, synthesizing oxalic acid from the neutral gaseous $\mathrm{CO}_{2}$. While calcium oxalate is produced in oxalate-precipitating plants grown on 
ammonium, the calcium oxalate content is increased when the plants are grown on nitrate (Raven $\&$ Smith 1976). The oxalate anion produced in neutralizing excess hydroxyl ions from the assimilation of nitrate into organic matter is often in part precipitated as calcium oxalate, thus avoiding generation of excess osmolarity and turgor (Raven \& Smith 1976; Raven 1977, 1985, 1986; Raven \& Farquhar 1990; Andrews et al. 2009). There are, of course, consequences for acid-base regulation of oxalate precipitation in ammonium-grown land plants. In roots the excess protons can be directly secreted to the rooting medium, while in shoots excess protons from oxalic acid synthesis and precipitation as calcium oxalate in ammonium-grown plants are neutralized by organic anions other than oxalate moved up the xylem and respired in the shoots with hydroxyl ion production; the excess protons generated in organic acid synthesis in the roots are excreted to the medium (Raven \& Smith 1976).

It turns out, however, that calcium oxalate crystals occur more widely within the Plantae, occurring in a number of coenocytic green ulvophycean algae (Pueschel \& West 2007a, and references therein) and florideophyte red algae (Pueschel 1995, Pueschel \& West 2007b 2007c), as well as in the microscopic filamentous green (charophycean) algal filament Spirogyra hatillensis (Pueschel 2001). Oxalic acid synthesis does not invariably involve calcium oxalate precipitation, since oxalate anions contributes about $20 \%$ to the vacuolar anionic charge in the giant-celled marine ulvophycean Acetabularia mediterranea (Saddler 1970) yet this organism has not been reported as precipitating calcium oxalate.. Little functional research has been done on calcium oxalates in algae, but the functions proposed for vascular plants by Franceschi and Nakati (2005) are at least plausible for other members of the Plantae. However, the absence of nitrate assimilation at a site remote from a medium that can act as a sink for excess hydroxyl ions in aquatic algae makes the stoichiometrically incontestable acid-base regulation role (Raven \& 
Smith 1976) less necessary, as well as being more costly of energy than hydroxyl ion excretion to the surrounding water (Raven 1985; Andrews et al. 2009). There does not even seem to be information on whether the nitrogen source has the any effect on the calcium oxalate content of algae.

Calcium oxalate has also been reported as an intracellular structure in fungi (Arnott 1995); once again its function is not well understood, but could include Ca-regulation and detoxification. Ca-regulation may also explain reports of other Ca-bearing minerals within protists, including calcium carbonate in diverse protists (Fauré-Fremiet 1957) and as aragonite in Spirogyra (Mann et al. 1988), gypsum in desmids (Brook 1981; Lowenstam 1986) and both calcite and Ca-phosphate (described as apatite, but possibly Ca-polyphosphate bodies) in the ciliates Spirostomum ambiguum (Jones 1967) and Euplotes eurystomus (Ruffalo 1978; Hausmann and Walz 1979). The acid-base regulation role mentioned for intracellular calcium oxalate, i.e. removal of excess hydroxyl ions in an osmotically unthreatening manner, also applies to intracellular calcium carbonate (Raven \& Smith 1976; Raven 1985), provided that the inorganic carbon source for the precipitated carbonate is endogenous (respiratory) carbon dioxide, carbon dioxide entering photosynthetic cells, or bicarbonate from the medium.

\section{DISCUSSION}

\section{The evolution of eukaryotic biomineralization}

In comparisons of biologically-induced mineralization by bacteria and skeletal biomineralization by eukaryotes, bacteria invariably seem the more diverse domain. When eukaryotic biomineralization, however, is expanded to include non-skeletal minerals precipitated within cells, eukaryotes deposit nearly as many minerals as do bacteria (Lowenstam 1986). Like 
most skeletal biominerals, these intracellular precipitates form in enclosed, biologically defined spaces (vesicles), guided by enzymatic activity. That is, they are at the less conspicuous end of a broad biomineralogical continuum that includes more familiar bones, shells, frustules and tests.

This being the case, it is instructive to ask why eukaryotes show only limited overlap in the minerals that they use for skeletons and other functions. The preceding discussion suggests that precipitation of specific non-skeletal minerals evolved under natural selection, exploiting the magnetic properties of magnetite, the specific gravity of barite and celestite, and the exchangable storage capacity of polyphosphates. One might equally ask why calcite, aragonite, dahllite and amorphous silica comprise the subset of eukaryotic biominerals involved in skeletal mineralization. Once again, material properties contribute to the explanation: composite materials of interlayered organic sheets and calcite or aragonite are mechanically resistant to abiological forces (especially for benthic organisms) and to forces exerted by grazers; these are functional prerequisites for many skeletons. Silica is not only rigid, resisting forces such as those that could be imposed by some grazers (Hamm et al. 2003; cf. Austin et al. 2005, who showed that diatom ingestion by foraminiferans resulted in fractured frustules, despite the absence of any obvious opposable rigid structures in these grazers), but can be fashioned into shapes of exquisite complexity within cells. Of course, function is only part of the explanation. The calcium and carbonate ions required for calcite and aragonite formation are abundant (surface seawater is strongly oversaturated with respect to these minerals at the moment, though this is subject to modification with global environmental change) and easily incorporated by organisms - all cells have fundamental mechanisms for pumping $\mathrm{Ca}^{2+}$ and manipulating total $\mathrm{CO}_{2}$. 
Considering in more detail intracellular mineralization in microbial eukaryotes, before the dramatic rise of diatoms to ecological prominence, surface oceans were saturated or nearly so with respect to amorphous silica, but abundances of silicified organisms was relatively low. The low concentrations of silicic acid in surface oceans and freshwaters containing diatoms required that silicic acid be concentrated to supersaturation in some compartment if silica minerals are to form (Raven 1983), an argument that also applies to formation of celestite in today's ocean. It is known that there was (polyphyletic) evolution of active transport mechanisms for silicic acid in all silicifiers (Raven \& Giordano 2009): this capacity is also found in some non-silicifying prasinophycean green algae (Fuhrman et al. 1978; Nelson et al. 1984). This may help to explain the predominance of silica in intracellular skeletal biomineralization (see Table 2) but of calcium carbonate minerals in those macroscopic skeletons of invertebrate metazoans and coenocytic and multicellular algae which are precipitated extracellularly, albeit often in spaces with relatively restricted diffusive interaction with the bulk medium and so susceptible to chemical modification and enzyme activity. Of course, supersaturation of the medium with respect to the mineral form to be precipitated does not preclude intracellular mineralization, as shown by calcite formation in coccolithophores and many foraminiferans (Table 2). While bacteria can clearly form intracellular biominerals, e.g. polyphosphate, within lipoprotein membranes (e.g. Rao et al. 2009; cf. the probably periplasmic status of the apparently intracellular bacterial magnetosomes: Komeili 2007), the absence of an endomembrane system means that they do not have the possibility of exocytosis of minerals such as can occur in eukaryotes.

Perhaps only in the cases of celestite and calcium phosphate mineralization do the realms of eukaryotic non-skeletal and skeletal bimineralization overlap. It must be noted that they overlap imperfectly, at least in the case of phosphates. It is possible that biochemical pathways 
originally evolved to control intracellular precipitation of polyphosphate bodies became co-opted for skeletal phosphate precipitation (see Rao et al. 2009). As noted above, the physiological cost of placing large amounts of phosphate in a non-exchangeable reservoir may help to explain why primary producers store polyphosphate but do not secrete phosphatic skeletons. The celestite found in acantharian skeletons may, however, reflect the direct evolutionary cooptation of mineralization pathways originally used for gravitropism.

\section{Biogeochemical consequences of eukaryotic biomineralization}

Skeletons have a well understood biogeochemical importance as the major means by which calcium carbonate and silica are deposited on the seafloor. What, if any biogeochemical function(s) can be ascribed to nonskeletal biominerals, recognizing that any such functions are presumably emergent properties of natural selection favouring mineral formation at the cell level?

Diaz et al. (2008) provided evidence consistent with a significant role for polyphosphates produced by diatoms in the formation of calcium phosphate minerals in marine sediments. Sanigrahi and Ingall (2005) had previously emphasized the importance of polyphosphates in increasing P fluxes in marine sediments overlain by anoxic waters, and Hopfer et al. (2007) indicated the role of polyphosphate produced within sediments in phosphate dynamics, although they could not quantify the involvement of microorganisms from the Archaea, Bacteria and Eukarya. With these interactions in mind, Algeo and Ingall (2007) indicated several possible roles for polyphosphate bodies in the deposition and retention of mineral phosphate in sediments. Balancing this, increasing geochemical data implicate absorption onto ferric oxide particles as a major means of getting phosphate into sediments and keeping it there, so a biogeochemical role 
for polyphosphates runs parallel to other processes at work in the marine phosphorus cycle (e.g., März et al. 2008).

A strong case can be made for the biogeochemical importance of celestite precipitation. In some parts of the ocean, e.g. the Indian Ocean just west of Australia, the rate of extraction of Sr by acantharians per unit volume of seawater is so great relative to the concentration of $\mathrm{Sr}$ in the top $400 \mathrm{~m}$ of the ocean that it very significantly exceeds the biological extraction rate of $\mathrm{Ca}$ relative to the $\mathrm{Ca}$ concentration. This results in significant decreases in $\mathrm{Sr} / \mathrm{Ca}$ in the surface ocean; dissolution of the acantharian skeletons at greater depths restores the conservative $\mathrm{Sr} / \mathrm{Ca}$ ratio (De Decker 2004). In laboratory experiments Bernstein and Byrne (2004) showed that the dissolution of acantharian celestite $(\mathrm{Ba} / \mathrm{Sr} \sim 0.003)$ leads to the production of barite. Dissolution of the celestite in a microenvironment leads to barite oversaturation and the production of Sr-rich barite of the kind that is ubiquitous in the water column (Bernstein \& Byrne 2004). This shows that Ba-containing acantharian celestite can be an important source of Sr-containing barite in the deeper parts of the ocean, and that acantharian production in surface waters can impact materially the distribution of both $\mathrm{Sr}$ and $\mathrm{Ba}$ in the oceans. Biologically influenced $\mathrm{Sr}$ abundances in surface oceans are of interest to paleoceanographers because $\mathrm{Sr} / \mathrm{Ca}$ in carbonate skeletons has been used as a proxy for seawater temperature in ancient oceans (de Villiers 1999; de Deckker 2004).

\section{CONCLUSIONS}

The diverse minerals considered here are united by being, for the most part, intracellular and non-skeletal. All increase cell density, but otherwise have a diversity of functions, including magnetoperception, graviperception, phosphate storage, calcium storage, and acid-base 
regulation. In addition, intercellular polyphosphate and celestite precipitation may be evolutionarily related to extracellular skeletal dahllite and celestite, and the relatively rare intracellular deposits of calcium carbonate and of silica (Table 2) may be analagous to early stages in the polyphyletic evolution of calcium carbonate and silica skeletons that are deposited internally and then exocytosed. Research on the diversity, physiology, function, phylogenetic distribution, and geobiology on non-skeletal minerals in eukaryotic cells is still in its infancy, but continuing work has much to tell us about how eukaryotes reflect and influence their environments.

\section{Acknowledgements}

The University of Dundee is a registered Scottish charity, No SC015096. AHK thanks the NASA Astrobiology Institute for research funding.

\section{References}

Algeo TJ, Ingall E. 2007. Sedimentary $\mathrm{C}_{\mathrm{org}}: \mathrm{P}$ ratios, paleocean ventilation, and Phanerozoic atmospheric $\mathrm{pO}_{2}$. Palaeogeography, Plaeoclimatology, Palaeoecology 256: $130-155$.

Anbar AD, Knoll AH. 2002. Proterozoic ocean chemistry and evolution: a bioorganic bridge? Science 297: 1137-1142.

Anderson OR. 1987. Fine structure of a silica-biomineralizing testate amoeba, Netzelia tuberculata. Journal of Protozoology 34: 302-309.

Anderson OR. 1994. Cytoplamic origin and surface deposition of siliceous scales in Sarcodina. Protopleasma 181: 61-77.

Anderson OR, Perry CC, Hughes NP. 1990. Transmission and scanning electronmicroscopic evidence for cytoplasmic deposition of strontium sulfate crystals in 
colonial radiolarian. Philosophical Transactions of the Royal Society of London B 329: 81-86.

Andrews M, Lea PJ, Raven JA, Azevedo RA. 2009. Nitrogen use efficiency. 3. Nitrogen fixation. Genes and costs. Annals of Applied Biology 155: 1-13.

Arnott HJ. 1995. Calcium oxalate in fungi. In: Khan SR. editor. Calcium Oxalate in Biological Systems.Boca Raton, FL: CRC. P.73-111.

Austin HA, Austin WEN, Paterson DM. 2005. Extracellular cracking and content removal of the benthic diatom Pleurosigma angulatum (Quekett) by the benthic foraminifera Haynesina germanica (Ehrenberg). Micopalaeontology 57: 68-73.

Baschnagel RA. 1966. New fossil algae from the middle Devonian of New York. Transactions of the American Microscopical Society 85: 297-302.

Bazylinski DA, Schlezinger DR, Howes BL, Frankel RB, Epstein SS. 2000. Occurrence and distribution of diverse populations of magnetic protists in a chemicallystratified coastal salt pond. Chemical Geology 169: 319-328.

Bazylinski DA, Frankel RB, Konhauser KO. 2007. Modes of mineralization of magnetite by microbes. Geomicrobiology Journal 24: 465-475.

Beardall J, Allan D, Bragg J, Finkel ZV, Flynn KJ, Quigg A, Richardson TAV, Raven JA. 2009. Allometry and stoichiometry of unicellular, colonial and multicellular phytoplankton. New Phytologist 181: 295-309.

Bernstein RE, Byrne RH. 2004. Acantharians and marine barite. Marine Chemistry 86: 45-50.

Bernstein RE, Byrne RH, Schijf J. 1998. Acantharians: a missing link in the oceanic biogeochemistry of barium. Deep-Sea Research Part I: Oceanographic Research Papers 45: 491-505.

Bock C, Jacob A, Kirst GO, Leinfritz D, Mayer A. 1996. Metabolic changes of the Antarctic green alga Prasiola stipitata subjected to water stress investigated by in vivo P-31 NMR. Journal of Experimental Botany 47: 241-249.

Bovee EC. 1981. Distribution and forms of siliceous structures among protozoa. In: Simpson TL, Volcani BE. Editors. Silicon and Siliceous Structures in Biological Systems. New York, NY: Springer-Verlag. P. 233-279.

Boyd CM, Gradman D. 2002. Impact of osmolytes on buoyancy of marine phytoplankton. Marine Biology 141: 605-618.

Brook AJ. 1981. Calcium-sulfate inclusions in the desmids Bambusina and 
Gonatozygon. British Phycological Journal 16: 267-272.

Cavalier-Smith T, Chao E E-Y. 2003. Phylogeny and classification of phylum Cercozoa (Protozoa). Protist 154: 341-358.

Chang SR, Stolz JF, Kirschvink JL, Awramik SM. 1989. Biogenic magnetite in stromatolites. II. Occurrence in ancient sedimentary environments. Precambrian Research 43: 306-315.

Chopin T, Lehmal H, Halcrow K. 1997. Polyphosphates in the red macroalga Chondrus crispus (Rhodophyceae). New Phytologist 135: 587-594.

Chopin T, Morais T, Belya E, Belfry S. 2004. Polyphosphate and siliceous granuales in the macroscopic gametophytes of the red alga Porphyra purpurea. Botanica Marina 47: 272-280.

Cobb AH. 1978. Inorganic polyphosphate involved in symbiosis between chloroplasts of alga Codium fragile and mollusk Elysia viridis. Nature 272: 554-555.

Darling KF, Thomas E, Kaemann SA, Seears HA, Smart CW, Wade CM. 2009. Surviving mass extinction by bridging the benthic/planktic divide. Proceedings of the National Academy of Sciences of the USA 106: 12629-12633.

de Decker P. 2004. On the celestite-secreting Acantharia and their effects on seawater strontium to calcium ratios. Hydrobiologia 517: 1-13.

de Nooijer LJ, Tokofuku T, Kitazato H. 2009. Foraminifera promote calcification by elevating their intracelluar $\mathrm{pH}$. Preceedings of the National Acxademy of Sciences USA 106 : 15374-15378.

de Villiers S. 1999. Seawater strontium and $\mathrm{Sr} / \mathrm{Ca}$ variability in the Atlantic and Pacific oceans. Earth Planetary Science Letters 171: 623-634.

Deslauriers R, Jarrell HC, Byrd RA, Smith ICP. 1980. P-31 NMR-studies of metabolism in Acanthanoeba castelanii - polyphosphate release from encysted cells. Biochemical and Biophyiscal Research Communications 95: 1`211-1217.

Diaz J, Ingall E, Benitz-Nelson C, Paterson D, de Jonge MD, McNulty I, Brandes JA. 2008. Marine polyphosphate: a key player in geologic phosphorus sequestration. Science 320: 652-655.

Docampo R, Moreno SNJ. 1999. Acidocalcisome: a novel $\mathrm{Ca}^{2+}$ storage compartment in trypanosomatids and apicomplexans. Parasitology Today 15: 443-448.

Docampo R, de Souza W, Miranda K, Rohloff P, Moreno SNJ. 2005. Acidocalcisomes conserved from bacteria to man. Nature Reviews Microbiology 3: 251-261. 
Domozych DS, Wells B, Shaw PJ. 1991. Basket scales of the green alga, Mesostigma viride: chemistry and ultrastructure. Journal of Cell Science 100: 397-407.

Dyhrman ST, Haley ST, Birkeland SR, Wurch LL, Cipriano MJ, McArthur. 2006. Long serial analysis of gene expression for gene discovery and transcriptome profiling in the widespread marine coccolithophorid Emiliania huxleyi. Applied and Environmental Microbiology 72: 252-260.

Eixler S, Karsten U, Selig U. 2006. Phosphorus storage in Chlorella vulgaris (Trebouxiophyceae, Chlorophyta) cells and its dependence on phosphate supply. Phycologia 45: 53-60.

Elgalish A, Elgalish GA, Halmann M, Berman T. 1980. Phosphorus utilization and storage in batch cultures of the dinoflagellate Peridinium cinctum f. westii. Journal of Phycology 16: 626-633.

Faivre D, Schüler D. 2008. Magnetotactic bacteria and magnetosomes. Chemical Reviews 108: 4875-4898.

Fauré-Fremiet E. 1957. Concrétions minérales intracytoplasmiques chez les Ciliés. Journal of Protozool 4: 96-109.

Franceschi VR, Nakata PA. 2005. Calcium oxalate in plants: formation and function. Annual Review of Plant Biology 56: 41-71.

Frankel RB, Bazylinski DA, Johnson M, Taylor BL. 1997. Magneto-aerotaxis in marine coccoid bacteria. Biophysical Journal 73: 994-1000.

Fresnel J. Galle P, Gayral P. 1979. Résultats de la microanalyse des cristeaex vacuolaires chez deux Chromophytes unicellulaires: Exanthemachrysis gayraliae, Pavlova sp. (Prymnesiophyceae). Comptes Rendues Academie des Sciences Paris 288: 823825.

Fuhrman JA, Chisholm SW, Guillard RRL. 1978. Marine alga Platymonas sp. accumulates silicon without apparent requirement. Nature 272: 244-246.

Gayral P, Fresnel J. 1979. Exanthemachrysis gayraliae Lepailleur (Prymnesiophyceae, Pavlovales): ultrastructure et discussion taxonomique. Protistologia 15: 271-282.

Gill BC, Lyons TW, Saltzman MR. 2007. Parallel, high-resolution carbon and sulfur isotope records of the evolving Paleozoic marine sulfur reservoir. Palaeogeography Palaeoclimatology Palaeoecology 256:156-173. 
Golden DC, Ming DW, Morris RV, Brearley A, Lauer HV, Treiman AH, Zolensky ME, Schwandt CS, Lofgren GE, McKay GA. 2004. Evidence for exclusively inorganic formation of magnetite in Martian meteorite ALH84001. American Mineralogist 89:681-695.

Hamm CE, Merkel R, Springer O, Kuoje P, Maler C, Prechtel K, Smetacek V. 2003. Architecture and material properties of diatom shells provide effective mechanical protection. Nature 421: 841-843.

Hausman K, Walz B. 1979. Ultrastructural characterization and energy dispersive-x-ray microanalysis of crystals and lithosomes of the ciliate Euplotes vannus. Protoplasma 99:67-77.

Heldal M. 1996. Polyphosphate bodies aligned along the anterior flagellum of the cryptomonad Rhodomonas lacustris: possible relevance to symbiotic origin of undulipodia. Symbiosis 21: $1-7$.

Hemmersbach R, Häder D-P. 1999. Graviresponses of certain ciliates and flagellates. FASEB Journal 13 (Supplement): S69-S75.

Hemmersbach R, Krause M, Bräucker R, Ivanova K. 2005. Graviperception in ciliates: Steps in the transduction chain. Advances in Space Research 35: 296-299.

Ho T-Y, Quigg A, Finkel ZV, Milligan AJ, Wyman K, Falkowski PG, Morel FMM. 2003. The elemental composition of some marine phytoplankton. Journal of Phycology 39: 1145-1159.

Hooley P, Whitehead MP, Brown MRW. 2008. Eukaryotic polyphosphate kinases: is the 'Kornberg' complex ubiquitous? Trends in Biochemical Sciences 33: 577-582.

Hopfer M, Gloess S, Grossart HP. 2007. Polyphosphate-accumulating microorganisms in aquatic sediments. Aquatic Microbial Ecology 47: 299-311.

Hughes NP, Perry CC, Anderson OR, Williams RJP. 1989. Biological minerals formed from strontium and barium sulfates. III. The morphology and crystallography of strontium sulphate crystals from the colonial radiolarian, Sphaerozoum punctatum. Proceedings of the Royal Society of London B 328: 223-233.

Jacobson L, Halmann M, Yariv J. 1982. The molecular composition of the volutin granule of yeast. Biochemical Journal 201: 473-479.

Jones AR. 1967. Calcium and phosphorus accumulation in Spirostomum ambiguum. Journal of Protistology 14: 220-225.

Keck B, Stich H. 1957. The widesporead occurrence oif polyphosphate in lower plants. Annals of Botany 21: 611-619. 
Kelman R, Feist M, Trewin NH, Hass H. 2004. Charophyte algae from the Rhynie Chert. Transactions of the Royal Society of Edinburgh 94: 445-455.

Kimura T, Watanabe M, Kohata K, Suedo R. 1999. Phosphate metabolism during diel vertical migration in the raphidophycean alga, Chattonella antiqua. Journal of Applied Phycology 11: 301-311.

Knoll AH. 2003. Biomineralisation and evolutionary history. In: Dove P, De Yoreo J, Weiner SJ, editors. Biomineralisation. Reviews in Mineralogy and Geochemistry 54: 329-256.

Komeili A. 2007. Molecular mechanisms of magnetosome formation. Annual Review of Biochemistry 76: 651-666.

Komine Y, Eggink LL, Park HS, Hoober JK. 2000. Vacuolar granules in Chlamydomonas reinhardtii: polyphosphate and a 70-kDa polypeptide as major components. Planta 210: 897-905.

Kreger DR, Boere H. 1969. Some observations on $\mathrm{BaSO}_{4}$ in Spirogyra. Acta Botanica Neerlandica 18: 141-151.

Kunimoto Y, Sarashina I, Ijima M, Endo K, Sashida K. 2006. Molecular phylogeny of acantharians and polycistine radiolarialians base on ribosomal DNA sequences, and some comparisons with data from the fossil record. European Journal of Protistology 42: 143-153.

Leitao JM, Lorenz B, Bachinski N, Wilhelm C, Muller WEG, Schroder MCl. 1995. Osmotic-stress-induced synthesis and degradation of inorganic polyphosphates in the alga Phaeodactylum tricornutum. Marine Ecology Progress Series 121, 279288 .

Lippert PC. 2008. Big discovery for biogenic magnetite. Proceedings of the National academy of Sciences of the USA 105: 17595-17596.

Lowenstam HA. 1986. Mineralization processes in monerans and protoctists. In: Leadbeater BSC, Riding R, editors. Biomineralization in Lower Plants and Animals. The Systematics Association Special Volume 80. Oxford, UK: Clarendon Press. P.1-17.

Mandernack KW, Bazylinski DA, Shanks WC III, Bullen TD. 1999. Oxygen and iron isotope studies of magnetite produced by magnetotactic bacteria. Science 285 : 1892-1896.

Mann S, Mann H, Fyfe WS. 1988. Intracellular aragonite crystals in the fresh-water alga, Spirogyra sp. Mineralogical Magazine 52: 241-245. 
Maranger R, Bird IF, Price NM. 1998. Iron acquisition by photosynthetic marine phytoplankton from ingested bacteria. Nature 396: 248-251.

März C, Poulton SW, Beckmann B, Küster K, Wagner T, Kasten S. 2008. Redox sensitivity of $\mathrm{P}$ cycling during marine black shale formation: dynamics of sulfidic and anoxic, nonsulfidic bottom waters. Geochimica Cosmochimica Acta 72: 3703-3717

Menge DNL, Levin SA, Hedin LO. 2008. Evolutionary tradeoffs can select against nitrogen fixation and thereby maintain nitrogen limitation. Proceedings of the National Academy of Sciences USA 105: 1573-1578.

Nelson DM, Riedel GF, Milan-Nunez R, Lara-Lara JR. 1984. Silicon uptake by algae with no known Si requirement. I. True cellular uptake and $\mathrm{pH}$-induced precipitation by Phaeodactylum tricornutum (Bacillariophyceae) and Platymonas sp. (Prasinophyceae). Journal of Phycology 20: 141-147.

Niemeyer R. 1976. Cyclic condensed metapolyphosphate and linear polyphosphates in brown and red algae. Archiv fur Mikrobiologie 108, 243-247.

Nishikawa K, Machida H, Yamakoshi Y, Ohmoto R, Saito K, Saito M, Tominga N. 2006. Polyphosphate metabolism in an acidophilic alga Chlamydomonas acidophila KT-1 (Chlorophyta) under phosphate stress. Plant Science 170: 307-313.

Nodwell LM., Price NM. 2001. Direct use of inorganic colloidal iron by marine mixotrophic phytoplankton. Limnology and Oceanography 46: 765-777.

Oku O, Kamatani A. 1995. Resting spore formation and phosphorus composition of the marine diatom Chaetoceros pseudocurivesetus under various nutrient concentrations. Marine Biology 123: 393-399.

Pawloski J, Holzman M, Berney C, Fahrni J, Gooday AJ, Cedhagen T, Hanura A, Bowser SS. 2003. The evolution of early Foraminifera. Proceedings of the National Academy of Sciences USA 100: 11494-11498.

Pueschel CM. 1995. Calcium oxalate crystals in the red alga Antithamnion kylinii (Ceramiales): cytoplasmic and limited to indeterminate axes. Protoplasma 189:73-80.

Pueschel CM. 2001. Calcium oxalate crystals in the green alga Spirogyra hatillensis (Zygnematales, Chlorophyta). International Journal of Plant Sciences 162:13371345.

Pueschel CM, West JA. 2007a. Cytoplasmic streaming of calcium oxalate crystals in Callipsygma wilsonis (Bryopsidales, Chlorophyta). Phycological Research 55:278-285. 
Pueschel CM, West JA. 2007b. Calcium oxalate crystals in the marine red alga Spyridia filamentosa (Ceramiales; Rhodophyta). Phycologia 46:565-571.

Pueschel CM, West JA. 2007c. Effects of ambient calcium concentration on the deposition of calcium oxalate crystals in Antithamnion (Ceramiales, Rhodophyta). Phycologia 46:371379

Rao NN, Gomez-Garcia MR, Kornberg A. 2009. Inorganic polyphosphate: Essential for growth and survival. Annual Review of Biochemistry 78: 605-647.

Raven JA. 1977. $\mathrm{H}^{+}$and $\mathrm{Ca}^{2+}$ in phloem and symplast: relation of relative immobility of ions to the cytoplasmic nature of the transport paths. New Phytologist 79: 565480 .

Raven JA. 1983. The transport and function of silicon in plants. Biological Reviews 58: 179-207.

Raven JA. 1985. Regulation of $\mathrm{pH}$ and generation of osmolarity in vascular land plants: costs and benefits in relation to efficiency of use of water, energy and nitrogen. New Phytologist 101: 25-77.

Raven JA. 1986. Biochemical disposal of excess $\mathrm{H}^{+}$in growing plants? New Phytologist 103: 625-643.

Raven JA. 1987. The role of vacuoles. New Phytologist 106: 357-422.

Raven JA, Smith FA. 1976. Nitrogen assimilation and transport in vascular plants in relation to intracellular $\mathrm{pH}$ regulation. New Phytologist 76: 415-431.

Raven JA, Farquhar GD. 1990. The influence of N-metabolism and organic-acid synthesis on the natural abundance of isotopes of carbon in plants. New Phytologist 109: 505-520.

Raven JA, Waite AM. 2004. The evolution of silicification in diatoms: inescapable sinking and sinking as escape? New Phytologist 162: 45-61.

Raven JA, Finkel ZV, Irwin AJ. 2005a. Picophytoplankton: bottom-up and top-down controls on ecology and evolution. Vie et Milieu 55: 209-215.

Raven JA, Brown K, Mackay M, Beardall J, Giordano M, Granum E, Leegood RC, Kilminster K, Walker DI. 2005b. Iron, nitrogen, phosphorus and zinc cycling and consequences for primary productivity in the oceans. In: Gadd GM, Semple KT, LappinScott HM, editors. Society for General Microbiology Symposium 65 Micro-organisms and Earth Systems: Advances in Geobiology. Cambridge, UK: Cambridge University Press. P 257-272. 
Raven JA, Giordano M. 2008. Biomineralization by photosynthetic organisms: Evidence of coevolution of organisms and their environment. Geobiology 7: 140-154.

Rieder N, Ott HA, Pfundstein P, Schoch R. 1981. X-ray microanalysis of the mineral contents of some Protozoa. Journal of Eukaryotic Microbiology 29: 15-18.

Romans KM, Carpenter EJ, Bergmann B. 1994. Buoyancy regulation in the colonial diazotrophic cyanobacterium Trichodesmium tenue - ultrastructure and storage of carbohydrate, polyphosphate and nitrogen. Journal of Phycology 30: 935-942.

Ross CA, Ross JRP 1991. Paleozoic foraminifera. Biosystems 25:39-51.

Rubetsov PM, Kulaev IS. 1977. Some pathways of polyphosphate biosynthesis and degradation in the green alga Acetabularia mediterranea. Biokhimiya 42: 10831089.

Ruffalo JJ. 1978. Intracellular calculi of the ciliate protozoon Euplotes eurystomus: Morphology, localization, and possible stages in formation. Transactions American Microscopical Society 97:381-386.

Ruiz FA, Marchesini N, Seufferheld M, Govindjee, Docampo R. 2001. The polyphosphate bodies of Chlamydomonas reinhardtii possess a proton-pumping pyrophosphatase and are similar to acidocalcisomes, Journal of Biological Chemistry 276: 46169-46203.

Rushdi AI, McManus J, Collier RW. 2000. Marine barite and celestite saturation in seawater. Marine Chemistry 69:19-31.

Saddler HDW. 1970. The ionic relations of Acetabularia mediterranea. Journal of Experimental Botany 21: 345-359.

Sanigrahi P, Ingall E. 2005. Polyphosphates as a source of enhanced P fluxes in marine sediments overlain by anoxic waters: evidence from ${ }^{31} \mathrm{P}$ NMR. Geochemical Transactions 6: 52-59.

Schroter K, Lauchli A, Sievers A. 1975. Microanalytical identification of barium sulphate in statoliths of Chara rhizoids (Ch.-fragilis). Planta 122: 213-225.

Schumann D, Raub TD, Kopp RE, Guerquin-Kern J-L, Wu T-D, Rouiller I, Smirnov AK, Sears SK, Lücken U, Tikoo SM, Hesse R, Kirschvink JL, Vali H. 2008. Gigantism in unique biogenic magnetite at the Paleocene-Eocene Thermal Maximum. Proceedings of the National Academy of Sciences 105: 17648-17653.

Scott DA, de Souza W, Bechimol M, Zhong L, Lu H-G, Moreno SNJ, Docampo R. 1998. The presence of a plant-like proton-pumping pyrophosphatase in acidocalcisomes of Trypanosoma cruzi. Journal of Biological Chemistry 273: 
22151-22158.

Siderius M, Musgrave A, van den Ende H, Koerten H, Cambier P, van der Meer P. 1996. Chlamydomonas eugametos (Chlorophyta) stores phosphate in polyphosphate bodies with calcium. Journal of Phycology 32: 402-409.

Sievers K, Schmitz M. 1982. X-ray analysis of barium, sulfur and strontium in statolith compartments of Chara-rhizoids. Berichte der Deutschen Botanischen Gesellschaft 95: 353-360.

Sims PA, Mann DG, Medlin LK. 2006. Evolution of diatoms: insight from fossil, biological and molecular data. Phycologia 45: 361-402.

Strullu DG, Harley JL, Gourret JP, Garrec JP. 1983. A note on the relative phosphorus and calcium comments of metachomatic granules in Fagus mycorrhiza. New Phyologist 94: 89-94.

Thomas-Keprta KL, Bazylinski DA, Kirschvink JL, Clemett SJ, Wentworth DS, Vali H, Gibson EK, Romanek CS. 2000. Elongated prismatic magnetite crystals in ALH84001 carbonate globules: Potential Martian magnetofossils. Geochim Cosmochim Acta 64: 4049-4081

Tiemann H, Sötje I, Jarms G, Paulmann C, Epple M, Hasse B. 2002. Calcium sulphate hemihydrates in statoliths of deep-sea medusae. Journal of the Chemical Society, Dalton Transactions 2002: 1266-1268.

Tiemann H, Sötje I, Becker A, Jarms G, Epple M. 2006. Calcium sulphate hemihydrate (bassanite) statoliths in the cubozoan Carybdea sp. Zoologische Anzeiger 245: 1317.

Torres de Araujo FF, Pires MA, Frankel RB, Bicudo CEM. 1986. Magnetite and magnetotaxis in algae. Biophysical Journal 50: 375-378.

Vali H, Kirschvink JL. 1991. Observations of magnetosome organization, surface structure, and iron biomineralization of undescribed magnetic bacteria: evolutionary speculations, in Frankel RP, Blakemore RP, editors. Iron Biomineralization. New York, NY: Plenum Press. P 97-115.

Van den Hoek C, Mann DG, Jahns HM. 1995. Algae: An Introduction to Phycology. Cambridge, UK: Cambridge University Press. 623 p.

Vitousek PM, Cassman C, Cleveland C, Crews T, Field CB, Grimm NB, Howarth RW, Marino R, Martinelli L, Rastetter EB, Sprent JI. 2002. Towards an ecological understanding of biological nitrogen fixation. Biogeochemistry 57/58: 1-45.

Waggoner BW. 1994. An aquatic microfossil assemblage from Cenomanian amber of 
France. Lethaia 27: 77-84.

Walsby AE, Reynolds CS. 1980. Sinking and floating. In: Morris I, editor. The Physiological Ecology of the Phytoplankton. Oxford, UK: Blackwell Science. P. 371412.

Weast RC, editor. 1979. CRC Handbook of Physics and Chemistry. Boca Raton, Florida: CRC Press.P. B212-B217.

Weiner S, Dove PM. 2003. An overview of biomineralization processes and the problemof the vital effect. In: Dove P, De Yoreo J, Weiner SJ, editors. Biomineralisation.Reviews in Mineralogy and Geochemistry 54: 1-29.

Werner TP, Amrhein N, Freimoser FM. 2007. Inorganic polyphosphate occurs in the cell wall of Chlamydomonas reinhardtii and accumulates during cytokinesis. BMC Plant Biology 7 Art No. 512007.

Yagisawa F, Nishida K, Yoshida M, Ohnuma, Shimada T, Fijiwara T, Yoshida Y, Misumi O, Kuroiwa H, Kuroiwa T. 2009. Identification of novel proteins in isolated polyphosphate vacuoles in the primitive red alga Cyanidioschyzon merolae. Plant Journal Accepted Article doi: 10.1111/j.1365-313X.2009.04008.x

Yoshisa M, Noel M-H, Nakayama T, Naganuna T. Inoye I. 2006. A haptophyte bearing siliceous scales: ultrastructure and phylogenetic position of Hyalolithus neopolis gen. et sp. nov. (Prymnesiophyceae, Haptophyta). Protist 157: 213-234.

Young JR, Henriksen K. 2003. Biomineralization within vesicles: the calcite of coccoliths. Reviews Mineralogy Geochemistry 54:189-215.

Zettler LA, Sogin MA, Caron DA. 1997. Phylogenetic relationships between the Acatharia and Polycistinea. A molecular perspective on Haeckel's Radiolaria. Proceedings of the National Academy of Sciences USA 94:11411-11416.

Zhang F, Sekine T. 2007. Impact-shock behaviour of Mg- and Ca-sulfates and their hydrates. Geochimica et Cosmochimica Acta 71: 4125-4133. 


\section{Table 1}

\section{Density of cell components in $\mathrm{kg} \mathrm{m}^{-3}$}

\begin{tabular}{lc} 
Magnetite & 5175 \\
Barite & 4500 \\
Celestite & 3960 \\
Dahllite & 3120 \\
Aragonite/Calcite & $2710-2930$ \\
Bassanite & 2750 \\
Gypsum & 2280 \\
$\begin{array}{l}\text { Opal } \\
\text { Polyphosphate }\end{array}$ & 1950 \\
$\begin{array}{l}\text { Nucleic acids } \\
\text { Polyglycan }\end{array}$ & 1700 \\
$\begin{array}{l}\text { Protein } \\
\text { Triglyceride }\end{array}$ & 1500 \\
$\begin{array}{l}\text { 1000 mol m } \\
\text { solutions of } \\
\text { intracellular } \\
\text { solutes } \\
\text { Seawater }\end{array}$ & 860 \\
$\begin{array}{l}\text { Air (as in } \\
\text { Cyanobacterial } \\
\text { gas vesicles) }\end{array}$ & 1.2 \\
\hline
\end{tabular}

From Weast (1979), Walsby \& Reynolds (1980), Jacobsen et al. (1982), Boyd \& Gradmann (2002), Zhang \& Sekine (2007) and (for dahllite) http://.www.geology.neab.net/minerals/carbapat/sort.htm. 


\section{Table 2}

\section{Non-skeletal minerals in eukaryotic microbes}

Based on Raven \& Giordano (2009),: see also Zettler et al. (1997), Kunimoto et al. (2006).

\begin{tabular}{|c|c|c|c|c|}
\hline Higher Taxon & Phylum & Class & Intracellular Minerals & References \\
\hline $\begin{array}{l}\text { Opisthokonta: } \\
\text { Fungi } \\
\text { Opisthokonta } \\
\text { Choanoflagella- } \\
\text { ta }\end{array}$ & & & $\begin{array}{l}\text { Ca oxalate } \\
\text { Polyphosphate } \\
\text { ( } \mathrm{SiO}_{2} \text { skeleton before exocytosis) }\end{array}$ & $\begin{array}{l}\text { Arnott (1995) } \\
\text { Keck \& Stich } \\
(1957) ; \\
\text { Jacobsen et al. } \\
(1982) ; \\
\text { Strulu et al. } 1983 . \\
\text { Bovee (1981) }\end{array}$ \\
\hline Amoebozoa & & & $\begin{array}{l}\text { Polyphosphate } \\
\text { (Skeletal } \mathrm{SiO}_{2} \text { particles before } \\
\text { exocytosis in some testate } \\
\text { species) }\end{array}$ & $\begin{array}{l}\text { Keck \& Stich } \\
(1957) ; \\
\text { Deslauriers } \\
\text { et al. (1980); } \\
\text { Anderson } \\
\text { (1987, 1994); } \\
\text { Hooley et al. } \\
\text { (2008) }\end{array}$ \\
\hline $\begin{array}{l}\text { Plantae } \\
\text { (Archaeo- } \\
\text { plastida) }\end{array}$ & Rhodophyta & $\begin{array}{l}\text { Cyanidiophyceae } \\
\text { Bangiophyceae } \\
\text { Floridiophyceae }\end{array}$ & $\begin{array}{l}\text { Polyphosphate } \\
\text { Polyphosphate, } \mathrm{SiO}_{2} \\
\text { Ca oxalate } \\
\text { Polyphosphate }\end{array}$ & $\begin{array}{l}\text { Yagisawa et al. } \\
\text { (2009); } \\
\text { Peuschel (1995); } \\
\text { Peuschel \& } \\
\text { West (2007a,b.c); } \\
\text { Niemeyer (1976); } \\
\text { Chopin et al. } \\
(1997,2004)\end{array}$ \\
\hline $\begin{array}{l}\text { Plantae } \\
\text { (Archaeo- } \\
\text { plastida) }\end{array}$ & Chlorophyta & Charophyceae & $\begin{array}{l}\mathrm{BaSO}_{4} / \mathrm{SrSO}_{4} \text { in intracellular } \\
\text { vesicles in desmids and } \\
\text { Zygnematales, statoliths in } \\
\text { rhizoids apices of Charales. } \\
\text { Occasional } \mathrm{CaSO}_{4} \text { in desmids. } \\
\mathrm{CaCO}_{3} \text { (aragonite) and } \mathrm{Ca} \\
\text { oxalate in Zygnematales } \\
\text { Polyphosphate }\end{array}$ & $\begin{array}{l}\text { Brook (1981); } \\
\text { Lowenstam } \\
\text { (1986); Schroter } \\
\text { et al. (1975); } \\
\text { Sievers and Schmitz } \\
\text { (1982);Mann et al. } \\
\text { (1988); Pueschel } \\
\text { (2001) } \\
\text { Keck \& Stich } \\
(1057)\end{array}$ \\
\hline $\begin{array}{l}\text { Plantae } \\
\text { (Archaeo- } \\
\text { plastida) }\end{array}$ & Chlorophyta & Chlorophyceae & Polyphosphate & $\begin{array}{l}\text { Keck \& Stich } \\
\text { (1957); } \\
\text { Siderius et al. } \\
\text { (1996); } \\
\text { Ruiz et al. (2001) }\end{array}$ \\
\hline Plantae & Chlorophyta & Prasinophyceae & $\left(\mathrm{SiO}_{2}\right.$ scales before exocytosis in & Bovee (1981) \\
\hline
\end{tabular}




\begin{tabular}{|c|c|c|c|c|}
\hline $\begin{array}{l}\text { (Archaeo- } \\
\text { plastida) }\end{array}$ & & & $\begin{array}{l}\text { a few) } \\
\text { Polyphosphate }\end{array}$ & $\begin{array}{l}\text { Hooley et al. } \\
(2008)\end{array}$ \\
\hline $\begin{array}{l}\text { Plantae } \\
\text { (Archaeo- } \\
\text { plastida) }\end{array}$ & Chrorophyta & Trebouxiophyceae & Polyphosphate & $\begin{array}{l}\text { Keck \& Stich } \\
(1957) ; \\
\text { Bock et al. (1996); } \\
\text { Eixler et al. (2006) }\end{array}$ \\
\hline $\begin{array}{l}\text { Plantae } \\
\text { (Archaeo- } \\
\text { plastida) }\end{array}$ & Chlorophyta & Ulvophyceae & $\begin{array}{l}\text { Polyphosphate } \\
\text { Ca oxalate }\end{array}$ & $\begin{array}{l}\text { Keck \& Stich } \\
\text { (1957); Rubetsov } \\
\text { \& Kulaev } \\
(1977) ; \text { Cobb } \\
(1978) \\
\text { Pueschel \& } \\
\text { West (2007a) }\end{array}$ \\
\hline Rhizaria & & $\begin{array}{l}\text { Acantharia } \\
\text { Radiolaria }\end{array}$ & $\begin{array}{l}\mathrm{SrSO}_{4} \text { in swarmers } \\
\text { (Skeletal } \mathrm{SrSO}_{4} \text { of Acantharia } \\
\text { before exocytosis) }\end{array}$ & $\begin{array}{l}\text { Hughes et al. } \\
(1989) ; \\
\text { Anderson et al. } \\
(1990)\end{array}$ \\
\hline Rhizaria & & Foraminifera & $\begin{array}{l}\text { (Skeletal } \mathrm{SiO}_{2} \text { in some) } \\
\text { (Skeletal } \mathrm{CaCO}_{3} \text { before } \\
\text { exocytosis in many) }\end{array}$ & $\begin{array}{l}\text { Bovee (1981) } \\
\text { Pawlowski et al. } \\
\text { (2003); De Nooijer } \\
\text { et al. (2009) }\end{array}$ \\
\hline Rhizaria & & $\begin{array}{l}\text { Euglyphida } \\
\text { Thaumato- } \\
\text { monadina }\end{array}$ & $\begin{array}{l}\text { (Skeletal } \mathrm{SiO}_{2} \text { before exocytosis } \\
\text { in many) }\end{array}$ & $\begin{array}{l}\text { Anderson (1994); } \\
\text { Cavalier-Smith and } \\
\text { Chao (2003) }\end{array}$ \\
\hline Alveolata & Ciliata & & $\begin{array}{l}\mathrm{Fe}_{3} \mathrm{O}_{4} \text { in a few } \\
\mathrm{BaSO}_{4} / \mathrm{SrSO}_{4} \\
\text { Polyphosphate? } \\
\mathrm{CaCO}_{3} \text { (calcite) }\end{array}$ & $\begin{array}{l}\text { Bazylinski et al. } \\
(2000) \\
\text { Rieder et al. (1981) } \\
\text { Hemmersbach and } \\
\text { Häder (1999); } \\
\text { Hemmersbach et al. } \\
\text { (2005); } \\
\text { Jones (1967), } \\
\text { Ruffalo (1978); } \\
\text { Hausmann \& } \\
\text { Walz (1979) }\end{array}$ \\
\hline Alveolata & Apicomplexa & & Polyphosphate & $\begin{array}{l}\text { Scott et al (1998); } \\
\text { Docampo \& } \\
\text { Moreno (1999); } \\
\text { Docampo et al. } \\
(2005) \\
\end{array}$ \\
\hline Alveolata & Dinophyta & & $\begin{array}{l}\mathrm{Fe}_{3} \mathrm{O}_{4} \text { in a few } \\
\text { Polyphosphate } \\
\text { (Skeletal } \mathrm{SiO}_{2} \text { before exocytosis) }\end{array}$ & $\begin{array}{l}\text { Bazylinski et al. } \\
\text { (2000); Elgalish } \\
\text { et al. (1980) } \\
\text { Bovee (1981) }\end{array}$ \\
\hline Chromista & Ochrista & Bacillariophyceae & (Skeletal $\mathrm{SiO}_{2}$ before exocytosis) & $\begin{array}{l}\text { Raven (1983); } \\
\text { Raven \& Waite } \\
\text { (2004); Keck }\end{array}$ \\
\hline
\end{tabular}




\begin{tabular}{|c|c|c|c|c|}
\hline & & Bicoseocida & $\begin{array}{l}\text { Polyphosphate } \\
\text { (Skeletal } \mathrm{SiO}_{2} \text { before exocytosis) }\end{array}$ & $\begin{array}{l}\text { \& Stich (1957); } \\
\text { Leitao et al. (1995); } \\
\text { Oku and } \\
\text { Kamatani (1995); } \\
\text { Bovee (1981) }\end{array}$ \\
\hline Chromista & Ochrista & $\begin{array}{l}\text { Chromomonado- } \\
\text { phyceae }\end{array}$ & Polyphosphate & $\begin{array}{l}\text { Kimura et al. } \\
\text { (1999) }\end{array}$ \\
\hline Chromista & Ochrista & Chrysophyceae & $\begin{array}{l}\text { (Skeletal } \mathrm{SiO}_{2} \text { of cysts before } \\
\text { exocytosis) }\end{array}$ & Bovee (1981) \\
\hline Chromista & Ochrista & Palmophyceae & (Skeletal $\mathrm{SiO}_{2}$ before exocytosis) & $\begin{array}{l}\text { Van den Hoek et al. } \\
\text { (1996) }\end{array}$ \\
\hline Chromista & Ochrista & Phaeophyceae & Polyphosphate & Niemeyer (1976) \\
\hline Chromista & Ochrista & Silicoflagellata & $\left(\right.$ Skeletal $\left.\mathrm{SiO}_{2}\right)$ & Bovee (1981) \\
\hline Chromista & Ochrista & Synurophyceae & (Skeletal $\mathrm{SiO}_{2}$ before exocytosis) & Bovee (1981) \\
\hline Chromista & Ochrista & Tribophyceae & Polyphosphate & $\begin{array}{l}\text { Keck and Stich } \\
\text { (1957) }\end{array}$ \\
\hline Chromista & Haptophyta & Pavlovophyceae & $\mathrm{BaSO}_{4} / \mathrm{SrSO}_{4}$ in a few & $\begin{array}{l}\text { Fresnel et al. } \\
(1979) ; \\
\text { Gayral \& Fresnel } \\
(1979)\end{array}$ \\
\hline Chromista & Haptophyta & Prymnesiophyceae & $\begin{array}{l}\text { (Skeletal } \mathrm{CaCO}_{3} \text { before } \\
\text { exocytosis in coccolithophores) } \\
\text { (Skeletal } \mathrm{SiO}_{2} \text { before exocytosis) } \\
\text { Polyphosphate }\end{array}$ & $\begin{array}{l}\text { Young \& } \\
\text { Henriksen } \\
\text { (2003); Raven } \\
\text { \& Waite (2004); } \\
\text { Yoshida et al. } \\
\text { (2006) Dyhrman } \\
\text { et al. (2005) }\end{array}$ \\
\hline Chromista & Cryptophyta & & $\begin{array}{l}\mathrm{Fe}_{3} \mathrm{O}_{4} \text { in a few } \\
\text { Polyphosphate }\end{array}$ & $\begin{array}{l}\text { Bazylinski et al. } \\
(2000) \\
\text { Heldal (1996) }\end{array}$ \\
\hline $\begin{array}{l}\text { Excavata/ } \\
\text { Discicristata }\end{array}$ & $\begin{array}{l}\text { Euglenophyta } \\
\text { Bodonida } \\
\text { Trypano- } \\
\text { somida }\end{array}$ & & $\begin{array}{l}\mathrm{Fe}_{3} \mathrm{O}_{4} \text { in a few } \\
\text { Polyphosphate } \\
\left(\mathrm{SiO}_{2} \text { scales before exocytosis) }\right. \\
\text { Polyphosphate }\end{array}$ & $\begin{array}{l}\text { Torres de Araujo } \\
\text { et al. (1986); Keck } \\
\& \text { Stich (1957) } \\
\text { Bovee (1981) } \\
\text { Docampo \& } \\
\text { Moreno (1999) } \\
\text { Docampo et al. } \\
\text { (2005) }\end{array}$ \\
\hline
\end{tabular}

